\title{
Customer Service in the United States
}

\author{
F. Robert Buchanan \\ M. Suzanne Clinton \\ University of Central Oklahoma
}

\begin{abstract}
This case examines the airline industry in the United States as an example of customer service. It uses authentic customer service letters as a springboard for a broader discussion of the current condition of customer service. Anyone who has received customer service from a large organization can relate to the content of this case, perhaps adding their own experiences. The case is applicable to both undergraduate and graduate courses in strategy, marketing, customer relationship management (CRM), and customer loyalty.
\end{abstract}

\section{Case Synopsis}

The United States has been characterized for a number of years as having shifted from a manufacturing economy to a service economy. Although consumers would reject poorly manufactured products, they regularly endure poor customer service. Service quality has been deteriorating in recent years and the behavior of service personnel is the primary cause (Patterson, McColl-Kennedy, Smith, \& Lu, 2009). Frankly, poor customer service is so rampant that people seldom stop to consider how common it is to encounter company representatives who are rude, careless, or poorly trained. Making matters worse are the systems that large companies have put into place to minimize the contact with customers in the course of their transactions. While customer service problems are prevalent in a broad array of industries, this case uses airlines as a showcase for customer service.

The case provides actual customer stories of interaction with airline industry personnel, along with industry trends, company profiles and performance comparisons of leading airlines. Both similarities and differences are observed. While the companies appear to have differences in their strategic missions, some of them face the same internal challenges, and they all share the same hyper-competitive external environment. Questions to consider include: Why do airlines handle customers the way they do? Are there any actions that might be recommended to address poor customer service in the airline industry? Does customer service really make any difference, and does customer service have any relevance to a company's competitiveness and performance in a globally competitive environment? 


\section{Introduction}

Contemporary customer service activities are being conducted in an environment that is often characterized by a high volume of transactions, low profit margins, and the use of technology. In situations where customers come into direct contact with company personnel, service representative competence and attitudes are particularly observable. Among the firms customers are familiar with contacting are mobile phone service providers, internet services, utility companies, consumer finance, and home mortgage lenders. This case focuses on airline customer service due to the nature of an industry that has a fairly limited number of competitors who must interact in person with their customers at a number of stages in the transaction process. While the purchase of tickets can be fully automated, other steps in the service delivery require direct contact with company personnel. Additionally, the complex nature of moving passengers to their destinations creates uncertainty and variability that cannot ever be fully automated. Some of the elements that must work together are the movement of airplanes, movement of passengers, and handling of baggage.

\section{Industry Environment: Airlines Bleeding Cash}

From its inception, air travel was a rather exciting and elegant process of boarding a gleaming aircraft for the premium experience of arriving at a destination in maximum speed and comfort. Travelers from those eras recall the courtesy and dignity of the process, as well as the accoutrements of hot meals with airline logo silverware on the trays. These services still exist today for first class ticket buyers, as well as with certain international carriers such as Emirates Airlines. Starting in the 1990's, airlines in the United States began to aggressively examine their distribution costs through ticketing, sales, and promotions. This led to cutting travel agents out of the reservations and ticketing process, for a savings of nearly $14 \%$ in operating costs (Doganis, 2006), in a process of dis-intermediation. With the advent of widespread access to high speed internet, reservations have been automated. This coincides with the elimination of tickets. From a customer perspective, the travel transaction has become a commodity in which ticket prices become the focus of an experience that sends travelers to the airport with nothing but a code number to use at a kiosk as they proceed through multiple queues and holding areas until they can be crowded into an aircraft seat. Any difficulties during the transaction process require the customer to make attempts to contact someone.

After weak performance in 2008, airlines in the United States went into a deep decline in 2009, as illustrated by the first quarter losses delineated in Table 1. By March, all were losing money. Not only were revenues down, but also passenger levels continued dropping (See Tables 2 and 3). Not since the aftermath of Sept. 2001 had the numbers looked so grim. Although overcapacities were reduced and fuel prices plummeted, revenues were hard hit by ticket discounting (See Table 4). By the end of April 2009, Domestic enplanements (the total number of passengers boarding) were down $9.7 \%$, while revenue passenger kilometers (RPKs) declined $9.6 \%$. RPK is a measure of traffic 
volume. It is based on the total distance flown by revenue-paying customers. Domestic revenue passenger-miles were down $10.2 \%$ (Corridore, 2009, p.1).

At the end of the third quarter in 2009 , the industry outlook continued to be described as volatile (Associated Press, 2009), primarily due to capacity running much higher than demand. Excess capacity creates downward pressure on ticket prices in general. The yields from premium fares fell much faster than the more price-sensitive economy segment, and the airlines became desperate for cash flow (IATA, 2009).

Table 1: 2009 First-Quarter Blues:

U.S. airline financial results in \$ millions (reported, unaudited)

\begin{tabular}{|l|c|c|c|}
\hline & Q1 net profit & Q1 net profit & Q1 operating profit \\
\hline & (loss) 2009 & (loss) 2008 & (loss) 2009 \\
\hline Delta & $(794)$ & $\left({ }^{*}\right)$ & $(483)$ \\
\hline American & $(375)$ & $(341)$ & $(194)$ \\
\hline United & $(382)$ & $(549)$ & $(282)$ \\
\hline US Airways & $(103)$ & $(237)$ & $(25)$ \\
\hline Continental & $(136)$ & $(82)$ & $(55)$ \\
\hline Southwest & $(91)$ & 34 & $(50)$ \\
\hline
\end{tabular}

$\left.{ }^{*}\right)$ Before merger with Northwest

Sources: Airline reports. (Schofield, 2009)

Table 2: Tickets sold and revenues per kilometer

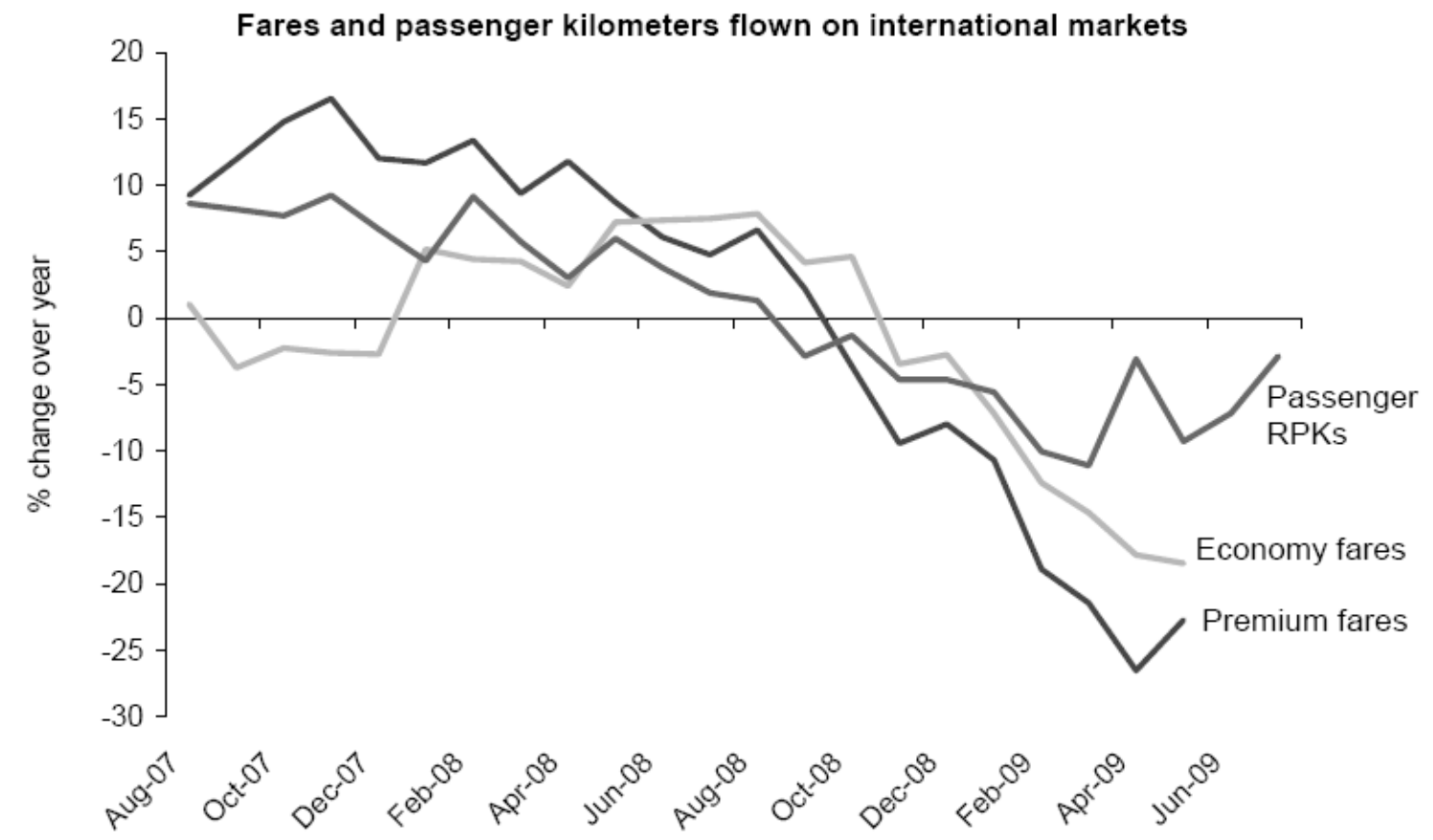

Source: PaxIS, IATA

(IATA, 2009) 
Table 3: Customer flight activity

Passenger Traffic Growth by Ticket Type

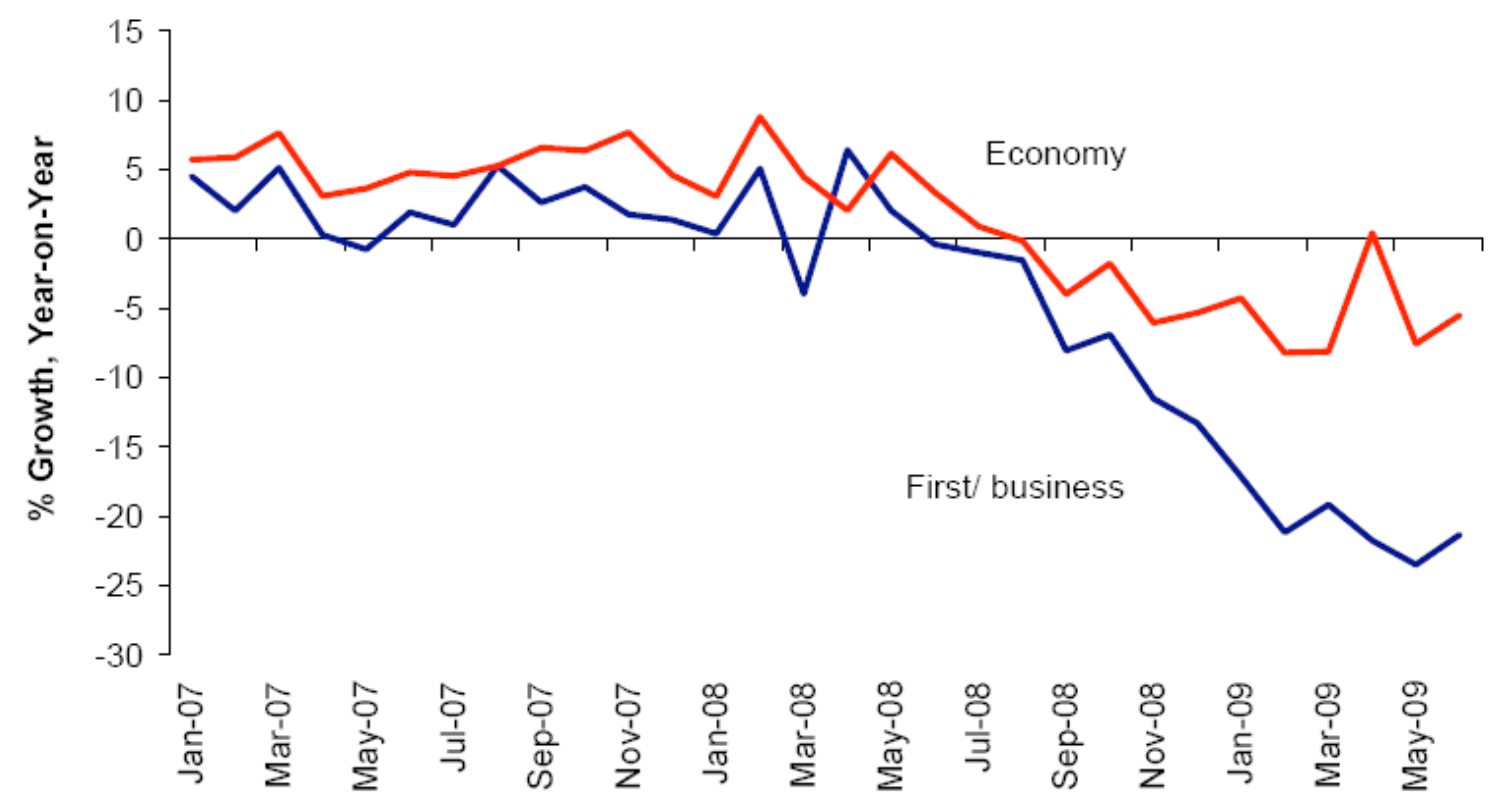

Source: IATA

(IATA, 2009)

Table 4: Industry profitability

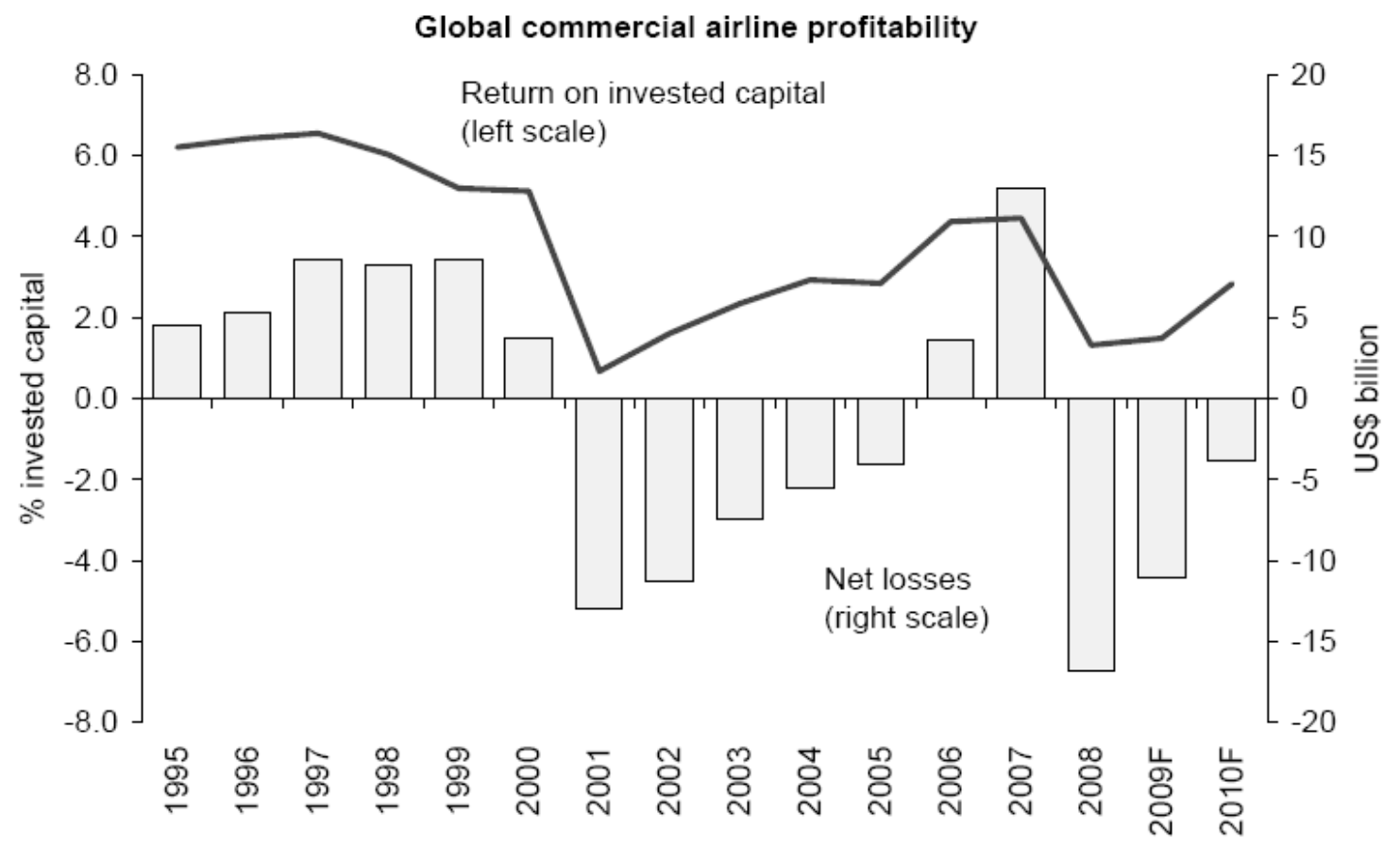

Source: ICAO, IATA

(IATA, 2009)

Copyright (c) 2010 Institute of Behavioral and Applied Management. All Rights Reserved. 
In addition to the losses experienced in the two quarters of 2009, the Air Transport Association of America, Inc. (ATA) "forecast that the number of passengers from June 1 through August 31, 2009, would drop 7\% to 195 million, from 209 million in the prior year - some 14 million fewer paying customers for the US airline industry during its seasonally strongest period" (Corridore, 2009, p. 1).

\section{Looking For Ways to Increase Revenues and Cut Costs}

Given the grim outlook for customer demand, airlines continued to look for ways to cut costs and increase revenues. Delta and United reduced the size of their fleets by retiring older, less fuel efficient aircraft. In April, 2008, American Airlines began charging a $\$ 25$ fee for the second bag each customer checked. The carrier described the checked baggage fee "as an 'a la carte' pricing model: an attempt to get passengers to pay more for the services they use" (Corridore, 2009, p.4). Less than one month later, American Airlines began charging a fee to check first bags as well. Most carriers followed American's leadership and began charging for all bags checked. "United Airlines announced that it would increase its first checked-bag fee by $\$ 5$ to $\$ 20$, highlighting how the industry is continuing to look to these fees as a potential source of revenue growth" (Corridore, 2009, p.4). Additional fees instituted by airlines as sources of revenue include fees for booking reservations by phone, canceling or changing reservations, additional fees for overweight baggage, charges for snacks, meals, and in some cases, in-flight drinks. "JetBlue Airways made news during the summer of 2008 when it started charging for a pillow and blanket" (Corridore, 2009, p.4).

In addition to increasing revenues, the aim of these fees is to reduce operating costs. Fewer bags mean less weight carried, and therefore less fuel used. Fewer meals reduce expenses and weight and perhaps allows for the elimination of bulky carts and kitchen galleys, creating space for additional seats. Selling tickets online has allowed airlines to "dramatically cut distribution costs by eliminating paper shuffling, bypassing agents, and reducing airline staff [and] has led to more competitive pricing" (Corridore, 2009 , p.16). Southwest led the industry in internet sales, with $78 \%$ of its sales booked through its own website (Corridore, 2009). Allowing customers to print boarding passes at home and use kiosks to check in luggage have also reduced the number of employees needed by the airlines.

\section{Customer Expectations}

Customers are not happy with airlines' cost cutting or revenue building measures. Further, customers seem less and less satisfied with the customer service they receive from the airlines. According to airline industry insiders and customer service experts, "[the airline industry is] just not a business that's wired for pleasing customers in the way that, for example, retailer Nordstrom is" (Reed, 2007, para.4). The airline industry will forever be below average in satisfying travelers... [because of] a business culture in which the costs of fuel and labor are viewed as more important than happy customers in determining profitability. Recent cuts may go too deep to ever deliver exceptional service, and perhaps customers don't appreciate the value of good service from airlines 
even when they get it (Reed, 2007, para.5). "It is unlikely that airlines will ever rank at the average, and certainly not above the average, in customer satisfaction because of some of the intrinsic factors ... that will never change," remarks David Grizzle of Continental Airlines" (Reed, 2007, para. 6).

Industry consultant Ira Gershkoff frets that carriers' focus on financial survival has made them blind to today's higher standards for satisfying customers. They do not seem to understand, he says, that U.S. consumers have been trained by customer oriented retailers to expect prompt - sometimes over-the-top - efforts to make them happy. Airlines "typically do not do that," he says. "Something goes wrong, [and] it's your problem" (Reed, 2007, para.21).

\section{Customer Experiences}

The following letters and travel narratives were written by airline customers. Company responses to the complaints are included. Contents of these letters illustrate the customer service provided by airlines profiled in this case. Actual customer service stories are as follows:

Sent to United Airlines

-----Original Message-----

Received: 7/27/2009 10:57:44 PM

Subject: Web Request for Customer Relations

Message type: Email Customer Relations Complaint

Dear Sirs,

In traveling from Bangkok, Thailand by myself with a small baby, we cleared customs at Dulles and had to physically move and re-check our luggage, only to discover you had already cancelled our flight home. Now we had no luggage and went to your customer service line, obviously exhausted after two days travel. Your representatives were furious that my baby would not stop crying and I responded that they were only embarrassed for all the other passengers to see that flying on United Airlines is a form of child abuse. Thank you for sending us to the Hyatt Reston. The complaint I filed with their general manager follows.

The next day I was unable to confirm my flights, again at your customer service counter at Dulles in Washington with a particularly rude agent who would identify herself only as T. Williams. I apologize for being likewise rude to her, but my patience was exhausted and the passenger who preceded me with T. Williams left in tears and I had been consoling her for the way United treated her.

This is the Email sent to the General Manager at Hyatt Reston.

Dear Mr. Eisenman, I am filing a complaint with United

Airlines about the way you handle their passengers. It was the result of a cancelled flight back to my home, and I was traveling by myself with a small baby. I accept the unavoidable difficulty and hazard in taking my baby out walking through the pouring rain to get diapers, baby food, and clean t-shirts after our two day trip from Bangkok through Paris and Frankfort to DC. However, I will not accept your refusal to bring us some food the next morning on the voucher which was printed to be good at all vendors in your hotel. Both James and Leenette refused to help me, and I had to wake the sick little jet lagged guy and take him to your restaurant and feed him baby food at the table with one hand while I tried to eat some eggs. I was stunned to see that it was the same menu as that in the room, coming from the same kitchen. I fully understand that flight cancelled hotel guests are tired, grouchy, and probably pretty difficult. However, if you can't handle the United account in a 
decent and professional way, you need to give up the contract and let

them get a better hotel than yours, perhaps Motel 6 .

\section{RESPONSE FROM THE AIRLINE:}

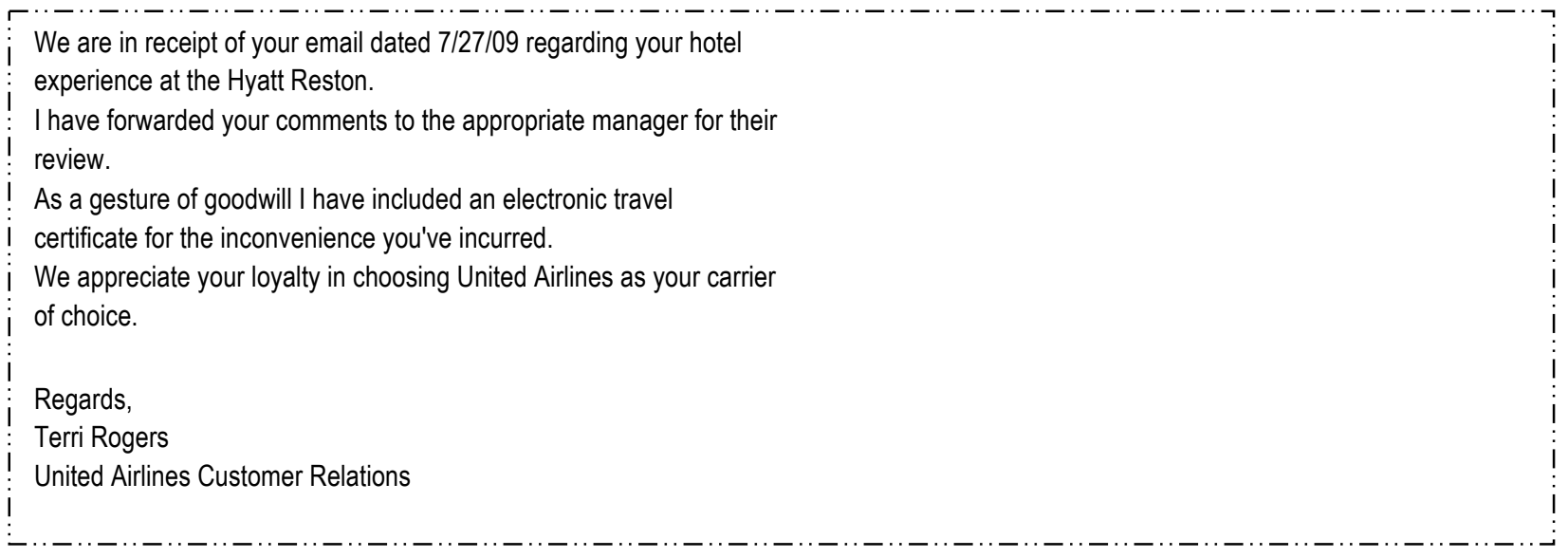

\section{RESPONSE FROM THE HOTEL:}

Dear Dr. Buchanan,

Thank you for allowing me the time to research your situation and speak to the parties involved regarding your recent stay at my hotel. I was most disappointed to learn of your frustrations with my front desk staff and wanted to contact you personally.

First and foremost, please accept my sincere apologies for the aggravation we caused when trying to utilize the meal voucher United Airlines provided you for use while a guest of our hotel. It is never our intention to frustrate our guests, and I am sorry that we were unable to meet your expectations. Typically we receive positive feedback on our front desk staff and services and it is most disturbing to know that we failed to provide the level of service expected of a Hyatt Hotel. I can certainly understand the confusion over the validity of the voucher in all hotel outlets due to the verbiage printed on the United Airlines voucher, but I wanted to clarify what United Airlines failed to inform it's travelers that evening. United Airlines does not cover In-Room Dining charges with it's meal vouchers. They only allow the usage of the voucher in the restaurant and will not recognize a room service meal as valid use of the voucher, and therefore, will not reimburse hotels for charges submitted as room service. Although we have asked that this exclusion be printed directly on the voucher to help avoid situations such as this, it has not yet been changed.

Nevertheless, I was embarrassed to read of your experience and would hope given your circumstances my staff would have found a creative way to assist you for breakfast so as not to further inconvenience you. I apologize for the unprofessional manner in which your situation was addressed and would like to stress that your experience is certainly not indicative of the level of service we consistently provide to our guests. I can assure you that I have addressed the service failures with my staff personally and thank you for bringing these matters to our attention as your feedback is very much appreciated and certainly a valuable aid in monitoring our performance. We will also make further contact with United Airlines to once again ask for their assistance in helping us eliminate this type of situation from happening again in the future.

Dr. Buchanan, my apologies again for a frustrating day of travel and the troubles you encountered at my hotel. I hope for the opportunity to earn back your business in the future.

Kind Regards,

Mario J. Terran 
June 18, 2002

American Airlines

Customer Relations

P.O. Box 619612

MD 2400

DFW Airport, TX 75261-9612

Dear American Airlines,

I had the unfortunate experience of traveling with AA June 13, 2002 from Atlanta to Oklahoma City. I arrived in Dallas at approximately 9:45 AM on June 13. At approximately 10:30 AM it was announced that my flight from Dallas to Oklahoma City would have a 10-minute delay due to a maintenance problem. We received approximately three of these messages. Then we received a sequence of announcements that the delay would be another 30 minutes. During each announcement, the gate agent told us not to leave the gate area, as all instructions would be broadcast at the gate only. Finally after two and one-half hours, we were instructed to board the bus at the gate.

When the bus arrived at the aircraft, we learned that the crew was not present. Do people at American Airlines talk to each other? Because no crew was present, we stood on the bus for forty-five minutes, at which time we were allowed to board the aircraft. Once on board the plane, the safety notices were given and we taxied to the runway. The passengers again began to worry as we sat on the runway for quite some time. Finally, the captain notified us that there was a storm between Dallas and OKC, and we would have to be re-routed around Abilene, requiring additional fuel. We taxied to the ramp and received the fuel. However, once we taxied back to the runway, the captain instructed us that the storm had moved and we were to fly even further south than planned. This change in plans required still more additional fuel, so the return to the ramp for refueling was repeated.

By this time, the storm had arrived in Dallas. We sat on the plane throughout the entire storm. Please understand that I acknowledge and appreciate the fact that no one can control the weather. However, if the flight had been managed properly in the first place, we would not have been stuck in Dallas while the storm was moving across the flight path.

Once the thunder and lightning stopped, we noticed that several other planes were taking off and landing. Passengers began to get angry and asked the Captain why we were not taking off while others were. He told us that we were unable to move until the blue flashing lights on the adjacent building stopped flashing. We explained to the Captain that plenty of traffic was moving about on the ramp, even though the blue lights continued to flash. We eventually learned, as I suspected, that the blue lights served no 
other purpose than to alert ramp traffic of the building's existence. It is hard to believe that both pilots were so poorly trained. Is anyone at American Airlines knowledgeable about anything?

It was at this point that the Captain contacted someone and learned the following aggravating information. The ground crew thought our plane was going to Des Moines or Boise, and so we now had 6,000 pounds too much fuel. Although the storm was now long over, we still could not leave because we now had to off-load 6,000 pounds of fuel to be able to land in OKC. The fuel truck arrived and began pumping out the fuel. This took quite a long time. All passengers were quite angry by now. We had been on the plane for approximately three hours and had not yet gone anywhere. As a matter of fact, we had only been offered a small beverage and one bag of pretzels.

We continued to sit on the plane at the ramp while the Captain returned to the main building to file another flight plan. This too, took an exorbitant amount of time. The passengers were getting more and more angry by the minute. Finally, the co-pilot announced that the Captain's flying time had expired and AA Flight 3553 was cancelled at 6:30 PM. You probably cannot imagine all of the comments that the passengers made! Did you not know that his flight time was about to expire? Could you not have gotten another pilot to fly us instead? Apparently our business is not at all important to American Airlines.

So, after staying on the bus for almost an hour and on the plane on the runway/ramp for four hours, we were loaded onto busses and taken back to the main terminal where we were told that we would have to rebook our flights. The gate agent initially told me that no flights to OKC were available until the following day. Then she put me on a standby flight. In three hours, I would have been able to rent a car and drive from Dallas to OKC. However, because of the extreme incompetence of American Airlines, I was still in Dallas. I could have driven to OKC at least twice by that time. The passengers were so upset by this time that the airline employees called the police.

In order to get to my gate, I boarded the bus to Terminal A2, where upon arrival, I learned that I needed my original ticket to get onto the standby flight. I tried to explain to the gate agent that my original ticket was taken by AA before I boarded the bus six hours earlier. She would not hear of it and told me to return to the main terminal, gate A7 and retrieve my ticket. I did return to gate A7 and that agent informed me that my ticket was indeed gone. Further, she told me that the agent at Terminal A2 could have called her for this information. She also told me that the gate for the 7:10 flight had been changed, and I did not need to return to Terminal A2. As you can imagine, I had had about all of the nonsense runaround that I could stomach. It was at this time that I learned that the 7:10 flight never materialized. We were now waiting for the 8:40 flight to OKC.

The 8:40 flight gate was changed again to Terminal A2. Once again, upon arrival at Terminal A2, we were told that the gate had again changed and we were all shuttled back to the main terminal. Before the night was over, we had changed gates over 5 
times after waiting on the bus for almost an hour and on the plane for over four hours. No one was happy.

Finally, we were sent back to Terminal A2 where upon we encountered the most unfriendly gate agent that I believe I have ever met. She did not make a wise decision when she chose to be rude to people who had by this time been trying to leave DFW for over ten hours.

We were told that additional delays were because the pilot had not arrived. Once the pilot arrived, we were told that even further delays were because the flight attendant had not arrived. Judging from my experiences on this day, missing and/or delayed pilots/crew seem to be the norm for American Airlines.

Finally, around $10 \mathrm{PM}$, we were allowed to board the plane to OKC. Once I arrived in $\mathrm{OKC}$, my boyfriend informed me that no one had told him that we were not coming to OKC until approximately $5 \mathrm{PM}$. He had asked the ticketing agents at OKC, and all they told him was that we left the gate at 1:00 PM. It seems to me that American Airlines failed once again. Did anyone even know that our plane was on the ground in Dallas? Would it have been too much to ask to have someone announce to all of those standing by in OKC that our flight had been delayed and then eventually cancelled? This is NOT customer service. My boyfriend made three twenty-five mile one-way trips to the OKC airport on June 13. I am sure that AA does not care, but he is employed as well. He had to take off work twice to come get me. He was home waiting to hear what had happened to me by the time I called him at 11:30 PM to come get me. If you need any additional information, please feel free to contact me.

Sincerely yours,

\section{August, 2008}

Mr. Gerard Arpey, CEO

American Airlines

4333 Amon Carter Blvd.

Fort Worth, TX 76155

Dear Mr. Arpey,

On August 13, 2008, your flight \# 2474 was three hours late leaving Los Angeles, causing my family to miss the last flight out of DFW to Oklahoma City. Upon arriving at DFW, I told your gate agent that I had to work the next day and she replied, "So what, I do too." This got us off to a very bad start with your personnel on the ground in Dallas.

Then your agent at the counter, while I held my sick, crying three-month old baby, informed me that my two choices were to sleep in the departure lounge or sleep in the motel for three hours. My request to her was to refund the unused ticket so that I could rent a car and drive three hours home. She scoffed at this request, which I fail to find 
the least bit unreasonable to have made. Customers should always be eligible for a prompt refund of unused product after a vendor-induced hardship.

Mr. Arpey, it is certainly your prerogative to treat customers in any way you wish. AMR is not alone in having poorly trained workers and a lack of civility to customers, which raises much concern about United States' general organizational competitiveness in the new global environment.

Sincerely yours,

FORM LETTER RESPONSE FROM AMERICAN AIRLINES (Identical to one received three years earlier relating to an entirely different incident):
August 27, 2008
After reading your letter, it is clear that we let you down - we apologize. Your comments serve as a reminder that we cannot afford to overlook our commitment to consistently provide quality service to our customers. I am truly sorry we disappointed you ... . etc. ... .
Sincerely, Lisa Glasper

May 29, 2003

To Whom it May Concern:

I would like to register a complaint against Northwest Airlines. Last October, my husband and I got bumped from a flight and spent eight hours in the Memphis airport. We opted to receive round trip tickets instead of the $\$ 300$ voucher. It seemed like an obvious choice until I realized that it is impossible to use the tickets.

Throughout the year, we have tried numerous times to use our tickets. We were flexible about the days and flexible about the airports. In every case we were told that there was no way to fly round trip to any of these places in any of the times or from any of the airports listed. So, we bought our own tickets and saved our free tickets. Ultimately we have discovered that in addition to "blackout" times and days, there are only so many seats per airplane that can use the free tickets, and of course, every flight I tried was already at their quota. I wonder if the quota is one.

The last time I talked to one of your representatives about this problem, he told me to NEVER take the free round trip tickets because they are practically useless-I should always take the money!!! This was one of your representatives telling a customer that I shouldn't have taken the reward offered because it was useless! 
I have been a loyal and frequent Northwest customer for many years. I enjoy the airline and would like to continue flying Northwest. However, I am really disappointed by these events.

\section{TRAVEL NARRATIVES:}

Six members of my family traveled in June 2006 on Delta airlines from Little Rock to Ft. Lauderdale for a Caribbean cruise. Shortly before time to load the plane, there was an announcement saying that the flight was canceled due to mechanical issues and that it would not be rescheduled for that day.

The Delta agent said that she could get us on a flight to Ft. Lauderdale the next day, which would make us miss our cruise. We asked if we could go on one of their partnership alliance flights or even drive to Memphis and catch a plane there. She said that they could not pay for us to go on any other plane, nor could they book us a Delta flight out of Memphis. We would have to pay for it ourselves. Since some in our party had used frequent flyer miles, she also said that they would not refund our miles. Nor would they give us a voucher for future use. She said her only responsibility was to get us to Ft. Lauderdale. She didn't seem bothered in the least by the fact that we had no reason to go to Ft. Lauderdale after missing our cruise!

We also tried talking to a manager and other agents, who again were not helpful. They were all consistent in reiterating that their only responsibility was to get us to our destination SOMETIME. Clearly they didn't care about our plight or the stress that we were experiencing.

As we tried to negotiate, beg, and barter with Delta, the rest of the group started visiting other airlines. Immediately, the Southwest Airlines agents were horrified by our situation. They had compassion and they really worked with us to try to find a flight for all of us. Granted, we had to pay for the flights, but it was the attitude that really mattered. They spent a long time searching for a variety of flight combinations that could get us to our destination on time. They asked other agents to help. They contacted other airports for us. They finally found a flight for all six of us to Chicago and a connecting flight for three of us to Ft. Lauderdale. They put the other three of us on stand-by. They contacted the gate in Chicago to tell them we were coming. As we were trying to decide whether to take this risky flight combo, they waited patiently, even delaying their departure for a few minutes as we scrambled at the last minute to make the decision. This even seems contrary to their fast-turnaround strategy, but I truly believe the agents were worried about us and wanted us to make it.

In Chicago, the three on standby did not get on the flight. The agents even asked if anyone on the flight would trade seats with us and take a later flight. The interesting thing was that they really seemed to care again about our plight. They empathized with us. That makes a big difference in a stressful situation. All of the Southwest employees we encountered were like this - they listened, they worked hard to help and they cared about the outcome. In fact, when my mom and I were crying on the plane because we 
left three of our group behind, the flight attendant gave us a glass of wine for free! And again, she cared. All of the Delta employees we encountered were the opposite-they didn't help much, and they definitely didn't seem to care at all. In fact, in Chicago, my brother went to the Delta counter again to see if they could help them get to Ft. Lauderdale on time, and the agent told him that he was "stupid" for not booking his flight through the cruise line and again that it was not Delta's responsibility. This may be true (that we should have booked through the cruise line), but it seems very unprofessional for an employee to call a customer "stupid" at any time!

When we came home from the trip, I wrote a letter to Delta. They eventually sent us each a $\$ 200$ flight voucher, a value far short of the lost frequent flyer miles, the additional ticket prices for all the additional flights, and hotel costs. Not wanting to fly Delta again. we tried to sign the vouchers over to my parents, but this proved very difficult. We had to accompany them to the airport and apply the vouchers to a specific flight that they were booking at that time.

Hello,

I only have a good story to share about Southwest. We recently traveled to Academy of Management conference in Anaheim. My wife relied on her electric scooter to get around Disneyland. Upon returning, the scooter no longer functioned at the departing gate. So one employee pushed my wife in a wheelchair to customer service near the baggage delivery (in Phoenix airport) but called another worker (not Southwest but airport bagger) to push the scooter to this center. The wheels were nearly locked and it was hard work pushing it nearly a half mile away (I helped too).

At customer service, they sent the scooter to a scooter repair shop and we are awaiting its delivery today (at home). I thought this was great service.

Professor $X$

\section{Company Specific Data and Information}

\section{Mission Statements}

Several airline carriers in the United States are highlighted in this case to serve as comparisons. These airlines include American Airlines, Delta, Northwest, Southwest, and United. The only one that uses a traditional standalone mission statement is Southwest, which appeared on their web site (Southwest, 2009) and was unchanged since 1998. The others seem to have either done away with the mission statement, or combined the mission statement with some other form of customer expectations disclosure. 
Statements of these companies are as follows:

\section{American Airlines}

American Airlines posts a Customer Service Plan under the heading of Customer Commitment on their web page (American Airlines, 2009). It states that "we are in business to provide safe, dependable and friendly air transportation to our customers, along with numerous related services. We are dedicated to making every flight you take with us something special. Your safety, comfort and convenience are our most important concerns."

Delta

Delta does not currently use a mission statement. Its Customer Commitment is outlined in the form of long legal document on its web site, filed under Legal Notices (Delta Airlines, 2009b). Upon trying to confirm the lack of a mission statement through a lengthy phone call on September 11, 2008, the hold queues went from the "Contact Us" staff to the web designer. Ultimately, Delta's phone representative tried to divert the call again to the frequent flier program or to car rental inquiries.

\section{Northwest}

Prior to the merger with Delta, Northwest's mission, vision, values, and guiding principles appeared on their web site in the following statement: "The vision of Northwest Airlines is to build together the first choice airline and global alliance network with the best people; each committed to exceeding our customers' expectations every day." Detailed commentary followed this sentence in sections headed Run a great airline, Put customers first, Focus on people, Build our network, and Secure our future (Northwest Airlines, 2008).

\section{Southwest}

"The mission of Southwest Airlines is dedication to the highest quality of Customer Service delivered with a sense of warmth, friendliness, individual pride, and Company Spirit" (Southwest Airlines, 2009).

\section{United}

Rather than using a mission statement, United has a thirteen page Customer Commitment pledge. It details 12 points of customer expectations (United Airlines, 2009).

\section{Company Performance Comparisons}

Gauging an Airline's Survival

Unrestricted cash is a common tool used by financial analysts to gauge airline survival. They use unrestricted cash to evaluate a carrier's liquidity and to determine how close an airline is to running out of cash. Calyon Securities analyst Ray Neidl considers a ratio of $10 \%$ or less to be the danger zone and ratios in the low and mid-teens worrisome. Neidl provided the ratios included below in Table 5, based on financial data as of June 
30, 2008 and June 30, 2009 (Peterson, 2009; Reed, 2008). The merger of Delta and Northwest prevent clear calculation of the ratios.

Table 5: Comparative Financials

Key Numbers

Ticker

2008 Sales (mil.)

2007 Sales (mil.)

1-Year Sales Growth

2008 Net Income (mil.)

1-Year Net Income Growth

Unrestricted cash (\% of sales) 2009

Unrestricted cash (\% of sales) 2008

2009 Employees

2008 Employees

1-Year Employee Growth

American Airlines
AMR
$\$ 23,800$
$\$ 22,935$
$3.6 \%$
$(-\$ 2,071)$
$(-75.8 \%)$
$12.2 \%$
$21.6 \%$
84,100
85,500
$(-1.6 \%)$

$\begin{array}{cc}\text { Delta } & \text { Northwest } \\ \text { DAL } & \text { NWA } \\ \$ 22,700 & \$ 11,279 \\ \$ 19,154 & \$ 12,528 \\ 18.5 \% & (-10.0 \%) \\ (-\$ 8,922) & (-\$ 862) \\ (-81.9 \%) & (-58.8 \%) \\ & \\ 16.1 \% & 24.5 \% \\ 84,306 & 14,663 \\ 55,044 & 34,000 \\ 34.7 \% & (-56.9 \%)\end{array}$

Southwest
LUV
$\$ 11,023$
$\$ 9,861$
$11.8 \%$
$\$ 178$
$(-72.4 \%)$
$19.4 \%$
$28.5 \%$
35,499
34,378
$3.2 \%$

United

UAL

$\$ 20,200$

$\$ 20,143$

$0.3 \%$

$(-\$ 5,348)$

$(-92.5 \%)$

$12.7 \%$

$14.1 \%$

50,000

55,000

(Hoover's Company Information, 2009, 2010a-

d;

Peterson, 2009)

\section{American Airlines}

\section{Company Profiles}

AMR, the parent company of American Airlines, was for many years the largest airline in the world. This changed in 2008 when Delta acquired Northwest. American Airlines lost two aircraft in the September 11, 2001, terrorist attacks on the World Trade Center in New York and the Pentagon in Washington, DC. Anticipating reduced demand for air travel, AMR reduced flights by $20 \%$ and laid off 20,000 employees. Unlike their competitors at Delta, Northwest, UAL, and US Airways, AMR was able to navigate the airline industry downturn that followed the September 11 attacks without making an emergency landing in bankruptcy court. Before the end of that year, tragedy struck another American Airlines jet which crashed in New York, killing all 260 passengers. American Airlines reduced its capacity, its fleet, and its workforce. Management squeezed concessions from its unions while awarding big bonuses to top executives, an inflammatory move which cost CEO Don Carty his job. His successor, Gerard Arpey, was another long-term insider of a failed management team at AMR.

The company lost money for next five years -- and piled up debt -- before posting profits in 2006 and 2007 (Hoover's Company Information, 2010a). In 2008, AMR went from a $\$ 450$ million previous year profit to a loss of $\$ 2$ billion (AirGuideBusiness.com, 2009). The company blamed the loss mostly on higher fuel costs (Maxon, 2008).

AMR's primary focus continued to be cost control, particularly in a high fuel cost environment. AMR planned to get rid of its American Eagle operations in order to increase shareholder value and establish a strategy of profitable growth. By means of 
either a spinoff or a sale to a third party, AMR would sharpen its focus on American Airlines. They reduced domestic capacity by $12 \%$ during 2008 . This involved the retirement of about 75 aircraft and the elimination of thousands of jobs. In the summer of 2008, American Airlines imposed customer charges for checking luggage, as well as fees for nearly all on-board items including pillows and blankets (Associated Press, 2008).

Along with boosting revenue and cost-cutting, American Airlines had maintenance issues with its fleet. Federal Aviation Administration inspectors found wiring problems in the aging MD-80 fleet. Three thousand flights were cancelled over several days in April 2008 for re-inspections. The cancellations created a huge ripple effect through all air traffic. In a separate case, the FAA levied fines against American Airlines for allegedly flying improperly maintained airplanes and for alleged failures to follow employee drugand alcohol testing procedures (Hoover's Company Information, 2010a).

American Airlines (AMR) Summary

AMR is the parent of American Airlines and American Eagle. Until 2008, AMR was the world's largest airline company, with broad global reach.

Financials.

Revenue for 2008: $\$ 23.8$ billion

Debt: $\$ 9$ billion

See Table 5: Comparative Financials

Strengths.

In U.S., strong hubs at Dallas/Fort Worth, Chicago and Miami;

Strong positions in New York and Los Angeles markets; leading carrier between U.S. and Latin America; and one of largest between U.S. and London's Heathrow Airport.

\section{Weaknesses.}

Middle-of-the-pack costs would be much lower but for high labor and fuel costs;

Poor and deteriorating labor relations, especially with pilots;

Mostly old, fuel-inefficient fleet of 960 mainline and regional planes inflates costs; and will take years to replace (Reed, 2008).

Delta

Delta acquired Northwest Airlines in 2008, becoming the largest airline in the world. The acquisition was a huge victory, following their bankruptcy. Delta and Northwest planned to focus on their transatlantic markets, along with their alliance with KLM. There were also further plans to expand into Asian, Pacific, and Chinese markets.

In 2005, Delta filed for Chapter 11 bankruptcy protection as a response to operational losses dating back to 2001. At that time, they secured $\$ 2$ billion in financing from creditors, chiefly GE Commercial Finance, in order to continue functioning. By the end of 2005, Delta had about 650 aircraft in its fleet, a reduction of nearly 200 planes from 
the year before. On April 30, 2007, Delta emerged from bankruptcy (Delta Airlines, 2009a).

Highly influential to this success was the 2006 labor contract in which Delta pilots accepted $\$ 280$ million per year in cuts resulting from pay, benefits, work rules, and most notably, the termination of the pilots' pension plans. Although unhappy, pilots were persuaded that a strike would have put Delta completely out of business.

To achieve a workforce reduction, Delta offered a buyout plan to workers in 2008 . The 4,000 that accepted the offer were double the number that management anticipated (Hoover's Company Information, 2010b).

\section{Delta Summary}

Formerly the USA's third-largest airline by revenue; Delta emerged from Chapter 11 bankruptcy reorganization in 2007 and moved rapidly in 2008 to acquire Northwest Airlines, picking up $\$ 2.8$ billion in debt.

Financials.

Revenue for 2008: $\$ 22.7$ billion

Debt: $\$ 15.4$ billion

See Table 5: Comparative Financials

Strengths.

With Northwest acquisition, becomes the largest airline in the world; Operating costs lowered via Chapter 11 bankruptcy during 2005-2007, though still among the highest;

Refocused route network to increase international service and reduce domestic flying; Powerful Atlanta hub is complemented by East Coast shuttle, Salt Lake hub and most U.S.-Europe service of any airline.

Weaknesses.

U.S. route system is still heavily dependent on smaller markets, where revenue often doesn't cover operating costs;

Exposure to lower-fare competition from AirTran in Atlanta;

Merger with Northwest creates a short-term cash drain before benefits appear (Reed, 2008).

\section{Northwest Airlines}

In April, 2008, Delta and Northwest announced their intention to combine in an all-stock transaction. By the end of the year, the merger was completed. The new company would ultimately operate under the Delta name and be based in Atlanta. The combined company would provide access to 390 destinations in 67 countries. The merger created the world's largest airline. The merger resulted in the elimination of 2,500 jobs. In the meantime, as they grappled with record fuel costs, Northwest joined American, United Airlines and US Airways in charging passengers $\$ 15$ to check a bag. Northwest also 
reduced its total mainline flight schedule by more than 9 percent during 2008, as well as cut about 8 percent of its total workforce. The goal was to eliminate management and frontline positions through voluntary programs and attrition (Baer, 2008).

Minnesota-based Northwest Airlines has a history of financial problems, union disputes, and customer service fiascos. In 1994, workers took three years of pay cuts in return for stock as a move to avoid bankruptcy. In 1998, pilot contract negotiations fell apart when Northwest proposed that some pilots accept less pay and more hours in order to become a low-fare airline. Sometimes known as "Northworst," much negative publicity surrounded a 1999 incident in which travelers were stranded for hours on runways in Detroit during a blizzard. The company finally agreed in 2001 to pay $\$ 7.1$ million to settle the class-action lawsuit that resulted (Hoover's Company Information, 2009).

Going into bankruptcy in 2005, Northwest cited high labor and operating costs, compounded by a jump in fuel prices. They had been cutting costs before the bankruptcy filing, but then asked for $\$ 176$ million in pay cuts from their mechanics, which resulted in a strike in August of that year. Striking mechanics were replaced by non-union workers. The bankruptcy gave Northwest more leverage in contract negotiations, and by 2006, Northwest had squeezed more pay and benefit reductions from its several unions, including pilots and machinists. Northwest exited Chapter 11 bankruptcy protection in May 2007 (Hoover's, 2009).

Northwest Summary

The fifth-largest U.S. airline by revenue; its merger with (acquisition by) Delta forms the world's largest carrier, topping American.

Financials.

Revenue for 2008: \$11.3 billion

Debt: Unclear due to merger

See Table 5: Comparative Financials

Strengths.

A premier U.S. - Asia route system;

Previously number 2 in unit revenue thanks to international network popular with business travelers and strong hubs in Detroit and Minneapolis-St. Paul that face relatively little competition from low-fare carriers;

Large fleet of high-capacity wide-body jets.

\section{Weaknesses.}

Highest unit costs among big airlines despite bankruptcy reorganization in 2005-2007; History of difficult labor-management relations; integration with Delta could be contentious;

Long-standing reputation for below-average customer service, despite evidence of recent improvement (Reed, 2008). 


\section{Southwest Airlines}

Southwest's corporate culture featured love as its theme from its earliest inception, serving 'love potions' (drinks) and 'love bites' (peanuts). In 1974 all other airlines moved to the new Dallas/Fort Worth Airport (DFW) but founder Herb Kelleher insisted on staying at Love Field, gaining a virtual monopoly there. A visionary and an industry maverick, Kelleher introduced advance-purchase Fun Fares in 1986 and a frequent-flier program in 1987 based on the number of flights taken instead of mileage. Sea World Texas made Southwest their official airline, which Kelleher commemorated by having a 737 painted as a killer whale (Hoover's Company Information, 2010c).

Simplicity has been a key element in Southwest's success. Traditionally, most of their flights are less than two hours in duration. They prefer small airports to avoid congestion and fees at competitors' larger hubs. Although originally created to serve Texas business centers, Southwest has grown well beyond its home region. Southwest's fleet of more than 500 aircraft consists only of one type -- the Boeing 737 -to minimize training and maintenance costs.

Southwest originated the no-assigned-seats boarding concept. Although not universally popular, it helps the carrier achieve quick turnarounds at airports and run consistently on-time departures. They modified their "cattle call" boarding system in 2007 by assigning passengers numbers within their boarding groups.

In 2008, the company finally lost money for the first time in its history. Its fuel hedging strategy failed when oil prices plunged, costing hundreds of millions of dollars. They were one of the few carriers that resisted the trend to charge for extras, and they allow a second checked bag for free. They allow small pets on board for $\$ 75$ and they only charge $\$ 50$ for a third bag or overweight bag. In 2009 , Southwest paid a fine to the FAA for missing 26 structural aircraft inspections (Hoover's Company Information, 2010c).

Southwest Summary

The industry's discount leader is No. 7 by revenue, but No. 1 in profitability.

Financials.

Revenue for 2008: $\$ 11$ billion

Debt: $\$ 3.5$ billion

See Table 5: Comparative Financials

Strengths.

Strongest balance sheet in the industry, with lots of cash and ready access to capital markets;

Sterling brand image; highly rated for customer service despite its no-frills approach; Best hedged against high fuel prices through 2012.

Weaknesses.

Cost pressures rising as growth slows; 
High fuel prices are pushing fares higher, threatening to send price-sensitive travelers - Southwest's core customers - to their cars (Reed, 2008).

\section{$\underline{\text { United }}$}

United was founded in 1929 by airplane designer Bill Boeing. After 30 years under one CEO, they went through long rounds of labor conflict that began in the 1980's. United lost two airplanes in the September 11, 2001 Islamic terrorist attacks.

In 1994, an employee stock ownership plan (ESOP) acquired 55\% of UAL, parent company of United Airlines. Unions found this to be the only way to stop the company from making big (and, with hindsight, essential) job cuts. After an initial success, the unions and management quickly reverted to confrontation. In 2002, United entered bankruptcy, and the ESOP became worthless (Economist, 2007).

In 2004, UAL renegotiated labor agreements, and won court permission to terminate its four employee pension plans. Employees also lost their controlling stake in the company. The federal Pension Benefit Guaranty Corporation wound up with responsibility for the pension plans and a stake in UAL. UAL emerged from bankruptcy protection in February 2006.

Some pilots and other United employees were angry about the company's three-year reorganization in bankruptcy that led to pay cuts for employees and a loss of retirement pensions and other benefits. The Air Line Pilots Association union pushed to open its contract for new negotiations (Hoover's Company Information, 2010d).

In 2008, United lost over $\$ 5$ billion and planned to have 9,000 total job reductions between 2008 and 2009. The corporate strategy became to focus on the high end of the market, particularly business and global travelers. They planned an extensive alliance with Continental Airlines.

In February 2009, United announced that it would stop publishing its customer relations phone number and close its call center that took compliments or complaints after a flight (WSJ, 2009). The company claimed that they would be better able to respond to customers who write to them.

\section{United (UAL) Summary}

United Airlines' parent, the USA's third-biggest airline company by revenue, emerged from bankruptcy reorganization in 2006.

Financials.

Revenue for 2008: $\$ 20.2$ billion

Debt: $\$ 7.2$ billion

See Table 5: Comparative Financials 


\section{Strengths.}

Best global service network, with big hubs in Chicago and Denver and a strong position at London Heathrow;

A premier network between U.S. and Asia;

Recently extended credit card partnership and banking relationships with Chase Bank to raise $\$ 600$ million in cash and improve liquidity by nearly $\$ 600$ million more.

\section{Weaknesses.}

Largest percentage income drop in the industry in 2008;

Aging fleet;

Increasingly contentious labor-management relations; pilots union calling for CEO

Glenn Tilton's resignation (Hoover's Company Information, 2010d).

\section{Does Customer Service Matter?}

Since 1994, Harris polls have consistently found more than $80 \%$ of Americans believe that big companies have too much power (Mokhiber \& Weissman, 2007). Trust in big businesses continued to decline in recent years, with less than $5 \%$ of respondents in 2007 finding oil, tobacco, and health care companies to be "generally honest and trustworthy." Insurance, pharmaceuticals, auto manufacturers, and airlines barely broke $10 \%$.

The following narrative is an excerpt from an article, "If the employees don't own it, your clients don't get it," written by Dave Bryan (2009), President and CEO of Blackdog Design/Build/Remodel. This excerpt is included to illustrate the vast difference in customer service provided by Southwest Airlines. The excerpt follows:

I am not trying to endorse [Southwest Airlines], but the company is a great example of how to do it right. I actually go out of my way to fly them, because their employees want me to be on their plane, and they let me know it every time. Southwest turns planes faster than anyone because their employees pull together. There are no prima donnas; everyone is willing to pitch in. Not only that, but they enlist my help. They ask me to take my trash with me, and - guess what - I do it. They make irreverent jokes during boarding and safety announcements. They keep my attention, ensure my safety, and make me laugh during a part of the flight that other airlines drone through with the creativity of a single-cell organism.

Southwest employees greet me, talk with me, and thank me with sincerity. If I have a connecting flight, they make sure to tell me where it will be. On some flights they play games. On some longer flights they grab kids and have them distribute the snacks. None of this stuff is rocket science, but it makes a difference and it can't be faked.

Here is the takeaway: Southwest is an employee-owned company. That is to say there is a palpable difference in how its people perform because they feel what they do is important to you, which is important to Southwest, which ultimately is 
important to them. You can't program people to be caring if they don't care. You can give them guidelines and rules and train them, but they are only as effective as their belief in the company. I am not suggesting you become an employeeowned company, although that idea has merit. I am suggesting you apply the same principles in your company as Southwest does in theirs.

Additional sources indicate that Southwest Airlines "reviews 216,000 resumes and hires about 5,000 employees," using group interviews which include Frequent Fliers as interviewers, as "they know what they're looking for in a new employee," (Gardner, 2001).

In relating customer service to profitability, author Fred Reichheld (2006) differentiates between bad profits and good profits. Through a simple metric based on the question of how likely a customer feels they are to recommend a company to a friend or colleague, good profits are identified as growth producers that are sustainable. Conversely, a bad profit indicator is associated with extracting value from customers rather than creating value. This takes place when a customer feels misled, mistreated, ignored, or coerced. Although bad profits can boost short term earnings, they burn out workers and alienate customers over the long run.

Customer service is just one of many aspects of the business model that impacts performance and overall success of an organization. For example, in the case of airline ticket prices, it is obvious that they are often too low to support strong profitability. Most organizations battle on many fronts in their strategic environment. Each industry is characterized by its own challenges. Although it is unreasonable to give unrealistic weight to the influence of customer service on organizational outcomes, it is instructive to analyze the similarities and differences between competitors and their styles of doing business.

Beyond that are broader questions about the condition of customer service in America. It is for each customer to observe and decide what level of customer service they will accept in markets that are served by multiple vendors. Demographics are applicable, as younger buyers do not have the memory of customer service levels from times of less technology and slower pace of business.

In considering the globally competitive business environment, concerns might be raised about vulnerability to competition from companies with superior service delivery. After all, in airlines as well as many other industries, everyone has essentially the same products and services. That leaves other less tangible elements as a method for a company to differentiate itself and create value.

\section{Case Exercises/Group Projects}

Exercise 1. Compare and contrast the airlines in this case regarding their growth, sales, net income, cash available, size of work force, and sales per employee.

Exercise 2. How much of the performance of the sample airlines do you think is related 
to the behavior and performance of employees? What are the elements that are influential to each of the selected airlines?

Exercise 3. Discuss your perceptions of customer service from the businesses you deal with, and the question of whether you would realistically pay higher prices for higher quality of customer service.

\section{Discussion Questions}

Question 1. How much direct impact does customer service have on a company's brand, image, or profits?

Question 2. What strategies might be applied in strengthening a company's ability to provide high quality customer service?

Question 3. Is there a difference between airlines based on their sales volume?

Question 4. Is there a difference between airlines based on their business models?

Question 5. Is there a difference between airlines based on the markets that they serve?

Question 6. What elements contribute to business failure in this industry?

Question 7. To what extent does airline customer satisfaction depend on the airlines' people and to what extent is customer service not a HR issue?

Question 8. To what extent does airline profitability depend on its people and to what extent does it depend on other elements?

Question 9. Compare the numbers of employees to sales. Why does Southwest seem to be so much more efficient?

\section{Questions for Additional Research}

Seven questions are included that require additional research through textbook, web, and/or scholarly databases.

Question 10. What are some of the reasons that service may vary between the airline companies?

Question 11. Why does Southwest Airlines seem to have a sustainable competitive advantage?

Question 12. How do you build or change a corporate culture?

Question 13. Is good customer service actually expensive for companies to provide?

Question 14. How do you analyze airlines from the US in comparison to foreign carriers?

Question 15. Conduct a Porter's Five Forces Analysis for the Airline Industry.

Question 16._ Conduct a SWOT Analysis for the Airline Industry.

\section{Questions Relating to Global Competitiveness}

Question 17. Why is customer service important in competitive global business environments?

Question 18. Will customers pay a higher price to cover costs of providing good 
customer service?

Question 19. How should airlines deal with customer service problems?

Question 20. Is it sufficient to deal with customer service problems by furnishing gift vouchers to those who complain?

Question 21. What actions can airlines take to prevent the frequency and number of customer service problems?

[Note: The Teaching Note for this case may be obtained by contacting Bob Buchanan at bucorama@gmail.com]

\section{References}

AirGuideBusiness.com (2009, April 27) Company Watch - American Airlines American Airlines (2009) Retrieved July 11, 2009 from: http://www.aa.com/aa/i18nForward.do?p=/aboutUs/customerCommitment/main.j $\mathrm{sp}$

Associated Press (2009, September 1). Airline industry lost over $\$ 6$ billion in $1^{\text {st }}$ half. Business News: Geneva.

Associated Press. (2008, May 21). American Airlines to charge for first checked bag. Retrieved Sept. 13, 2008 from: http://www.suntimes.com/news/nation/962051,american052108.article

Baer, J. (2008, July 24). Northwest flies into $\$ 377 \mathrm{~m}$ loss. Financial Times, London, 16 .

Bryan, D. (2009, July). If the employees don't own it, your clients don't get it. Professional Remodeler, 13(7), 15.

Corridore, J. (2009, June 18). Standard \& Poor's Industry Surveys: Airlines.

Delta Airlines (2009a) Retrieved July 11, 2009 from: http://images.delta.com.edgesuite.net/delta/pdfs/annual_reports/2007_10k.pdf

Delta Airlines (2009b) Retrieved July 11, 2009 from: http://www.delta.com/legal/delta_customer_commitment/index.jsp

Doganis, R. 2006. The airline business $\left(2^{\text {nd }}\right.$ edition $)$. New York: Routledge.

Economist Intelligence Unit Ltd. (2007, April 13) USA finance: An ESOP to the workers. EIU ViewsWire, New York.

Gardner, J. (2001, October 29). 10 Great Ideas for Growing Business Now. Inc.

Mokhiber, R., \& Weissman, R. (2007). Neither Honest Nor Trustworthy:

The 10 Worst Corporations of 2007. Multinational Monitor, 28(5), 10-30.

Northwest Airlines (2008). Retrieved September 5, 2009 from: http://www.nwa.com/corpinfo/profi/vision/

Patterson, P., McColl-Kennedy, J., Smith, A., \& Lu, Z. (2009) Customer rage: Triggers, tipping points, and take-outs. California Management Review, 52(1), 6-28.

Peterson, K. (2009, May 4) US airlines running a little low on cash: Experts. Reuters. Retrieved July 11, 2009 from: http://www.reuters.com/article/reutersEdge/idUSTRE5434RV20090504

Reed, D. (2008, August 20). Which airlines have the most financial staying power? USA Today. Retrieved July 11, 2009 from: http://www.usatoday.com/travel/flights/2008-08-20airlines-with-most-staying-power_N.htm Retrieved Sept. 22, 2009 from: http://www.inc.com/articles/2001/10/23629.html 
Hoover's Company Information: (2010a). AMR. Retrieved April 28, 2010 from:

http://www.lexisnexis.com/us/Inacademic/results/docview/docview.do?docLinklnd $=$ true \&risb=21_T9212524953\&format=GNBFI\&sort=BOOLEAN\&startDocNo=1\&r esultsUrlKey=29_T9212524956\&cisb=22_T9212524955\&treeMax=true\&treeWidt $\mathrm{h}=0$ \&csi $=220620 \&$ doc No $=12$

Hoover's Company Information: (2010b). DAL. Retrieved April 28, 2010 from:

http://www.lexisnexis.com/us/Inacademic/results/docview/docview.do?docLinklnd =true\&risb=21_T9213049180\&format=GNBFI\&sort=BOOLEAN\&startDocNo=26\& resultsUrlKey $=29 \_$T9213049183\&cisb $=22 \_$T9213049182\&treeMax $=$true\&treeWid th $=0 \& \mathrm{csi}=220620 \&$ docNo $=44$

Hoover's Company Information: (2010c). LUV. Retrieved April 28, 2010 from:

http://www.lexisnexis.com/us/lnacademic/results/docview/docview.do?docLinklnd =true\&risb=21_T9212714288\&format=GNBFI\&sort=BOOLEAN\&startDocNo=26\& resultsUrlKey $=29 \_$T9212714293\&cisb $=22 \_$T9212714292\&treeMax $=$true\&treeWid th $=0 \& \mathrm{csi}=220620 \& \mathrm{docNo}=41$

Hoover's Company Information: (2010d). UAL. Retrieved April 28, 2010 from:

http://www.lexisnexis.com/us/Inacademic/results/docview/docview.do?docLinkInd $=$ true \&risb=21_T9213009161\&format=GNBFI\&sort=BOOLEAN\&startDocNo=51\& resultsUrIKey=29_T9213009164\&cisb=22_T9213009163\&treeMax=true\&treeWid th $=0 \&$ csi $=220620 \&$ docNo $=68$

Hoover's Company Information: (2009). NWA. Retrieved Jan 10, 2009 from: http://www.hoovers.com/simple/xmillion/index.xhtml?query_string=nwa\&which=c ompany\&page=1\&search_x=18\&search_y=12

IATA (2009).Financial forecast: September 2009. Retrieved September 22, 2009 from: http://www.iata.org/NR/rdonlyres/DA8ACB38-676F-4DB1-A2AC-

F5BCEF74CB2C/0/Industry_Outlook_Sep09.pdf

Maxon, T. (2008, April 17). American Airlines parent AMR loses $\$ 328$ million, blames rising fuel prices. The Dallas Morning News.

Reed, D. (2007, October 17). Will fliers ever smile or are the U.S. airlines destined to disappoint?; Cuts in costs and labor blamed for poor customer service, but passengers also tough to please. USA Today. Retrieved September 12, 2009.from http://www.usatoday.com/travel/flights/2007-10-17-will-fliers-ever-smile_N.htm

Reichheld, F. (2006). The ultimate question: Driving good profits and true growth. Boston: Harvard Business School Press.

Schofield, A. (2009, April 27). Traffic Trough. Aviation Week \& Space Technology, 170(17), 00052175.

Southwest Airlines (2009). Retrieved July 11, 2009 from: http://www.southwest.com/about_swa/mission.html

United Airlines (2009). Retrieved July 11, 2009 from: http://www.united.com/page/article/0,6722,1505,00.html

WSJ. (2009, February 11). United Airlines to unplug number for complaints. Wall Street Journal - Eastern Edition, 253(34), D6, 0p. 